\title{
THE EFFECTS OF IFRS ADOPTION ON TAXATION IN NIGERIAN MANUFACTURING COMPANIES
}

\section{Tajudeen Adejare Adegbite}

\author{
Al-Hikmah University, Ilorin, Nigeria \\ e-mail: adetajud@yahoo.com
}

ORCID: 0000-0001-7456-0172

(C) 2020 Tajudeen Adejare Adegbite

This work is licensed under the Creative Commons Attribution-ShareAlike 4.0 International License. To view a copy of this license, visit http://creativecommons.org/licenses/by-sa/4.0/

Quote as: Adegbite, T. A. (2020). The effects of IFRS adoption on taxation in Nigerian manufacturing companies. Financial Sciences, 25(4).

DOI: 10.15611/fins.2020.4.01

JEL Classification: H25, G120, E220, E22, K230

\begin{abstract}
This study examined the effect of IFRS adoption on manufacturing companies' tax payable from 2012 to 2018. Data gathered from the annual reports of fifty selected Nigerian listed companies were scrutinised employing PPMC and panel data methodology to quantify the effect of IFRS adoption on tax payable. It revealed that Profit before tax (PBT) caused a positive and significant effect on TAXATION, whereas Depreciation (DEPR), Shareholders' Funds (SHDFUD), Long-term debt (LGTDEBT), and Noncurrent Asset (NONCURASET) impacted on TAXATION negatively. This showed that an surge in DEPR, SHDFUD, LGTDEBT and NONCURASET diminished TAXATION in manufacturing companies. Conclusively, IFRS adoption significantly downplayed manufacturing companies' tax payable because organisations circumspectly and lawfully circumvent or reduce the tax payable through depreciation claimed on existing assets, the procurement of new noncurrent assets, and long term debt (leverage). It is advocated that there should be monitoring mechanism devices put in motion by the government to monitor procurement by companies, impairment of assets and debts acquired transparently, in order to deter the unnecessary and artificial reduction in tax payable.
\end{abstract}

Keywords: depreciation, taxation, shareholders' funds, long-term debt, noncurrent asset, IFRS.

\section{Introduction}

International Financial Reporting Standards (IFRS) is an accounting standard engaged globally for international uniformity, comparability and consistency in financial transactions and reports. It replaced GAAP in Nigeria which was unanimously adopted in 2012. Before the commencement of IFRS, prepared and reported financial statements were drawn up in Nigeria through SAS which was produced by the Nigerian Accounting Standards Board (NASB) which issued 
Statements of Accounting Standards (SAS) as a yardstick in preparing the financial statement in the past by companies so as to promote and enforce standards compliance. However, SAS is now considered outdated by the International Accounting Standards Board (IASB) (cf. Fasina \& Adegbite, 2014). This is an independent private sector body that develops and approves International Financial Reporting Standards (IFRSs) with the motives of conformity and uniformity. IASB Nigeria joined their counterparts in the world to abandon the old and outdated accounting standard, and embraced fully IFRS in 2012. Since the adoption of IFRS in 2011, every company which is owned by private individual and organization has discarded the outdated accounting standard, and switched to IFRS (Ezejiofor, 2018). The IFRS' adoption has been confirmed to initiate the stance of the reporting entities in Nigeria to comply with the adopted newly standards in their counterparts worldwide, which would improve their reporting and gain worldwide recognition (Josiah, Okoye, \& Adediran 2013). IFRS are being employed globally for the preparation of financial statements and reporting for privately owned organisations. It has opened global attention for the effective and efficient improvement on financial statement reporting in terms of fairness, comparability, uniformity, and the consistent presentation of financial statements. IFRS adoption necessitates the important costs' reduction, increases capital allowance and has significance for organizations in terms of fraud prevention, proper accountability, consistent transaction treatment, and financial statement reporting for both internal and external users.

IFRS are established through an international process that encompasses financial analysts, accountants and other financial statements users such as stock exchanges, the business community, legal and regulatory authorities, academics and interested organizations and individuals from around the world. IASB conducted due process which has the complete obligation for technical issues comprising the standards issuance and publication with its explicit interpretations. This IFRS adoption as implemented by IASB, determines the qualities of standards in financial reporting. It also enhances the quality of reporting financial information especially, with regard to the perception of tax. All organisations are mandated to report current tax to the tax authority at the end of every financial reporting year. It is also mandated in IAS12 that organisations must classify the over or under-provision of current tax concerning prior year(s). Over-provision refers as tax income, while under-provision is called tax expense. A company's financial reporting is effected through the preparation, readiness and publication of financial statements. These financial statements are mandatory to show certain quality in tandem with tax remitted to FIRS, but does the fulfilment of IAS 12 on the remittance of current tax to the tax offices responsible for tax collection, have an effect on tax remittance by Nigerian manufacturing companies? Many studies have been carried out on IFRS adoption in Nigeria but there are no extant research on the effect of IFRS adoption on tax payable by manufacturing companies in Nigeria. This study therefore examines the effect of IFRS adoption on 
tax remitted to the Federal Inland Revenue Services of Nigeria (FIRS), responsible for tax collection, by manufacturing companies in Nigeria. To achieve this objective, this study was structured into five parts: the background of the study, literature review, methodology, and a discussion of the findings. The last part is the conclusion and recommendations. This study is expected to contribute to the subject knowledge through the methodology and research literature in gauging the effect of IFRS adoption on tax payable by manufacturing companies in Nigeria.

\section{Literature review and hypotheses}

\subsection{Influence of IFRS on taxation}

Tax income (tax expenses) is the cumulative amount engaged in deciding Profit and Loss for the period in regard of current and deferred taxes. The main concern treated by IAS 12 is the management of current and deferred taxes. It is also mandatory to specify whether there is an over-provision or under-provision of tax in respect to prior year(s). Tax over-provision is recognised as a tax income, while under-provision is recognised as an extra tax expense, both must be included in Profit and Loss for the period they are recognized. Deferred tax comprises associating the carrying amount (CA) of liabilities and assets with the tax bases (TB). The tax base is the volume ascribed to liabilities and assets for tax purposes. IFRS implementation also brings the prospect to decrease tax payable. The IFRS financial report serves as a basis for manipulative tax income. Eberhartinger and Klostermann (2007) stated that the custom of IFRS on tax calculation simplifies the reporting process and invariably reduces the cost of compliance. However, recognition of the tax basis through IFRS increases tax payable (Haverals, 2007). Therefore, by referring to the above, the following hypothesis is proposed.

\section{H1: IFRS has a significant impact on taxation of Nigerian manufacturing companies.}

\subsection{Depreciation}

This is called the wear and tear of an asset, and is measured and calculated through two accepted methods. The straight line and reducing balance methods are engaged officially to calculate the depreciation of Plant property and equipment (PPE) according to IAS 16 , whilst according to IAS $16 \&$ IAS 38, the depreciation procedure for depreciable assets leased must be consistent with depreciable assets owned. This is based on the shorter of the useful life and lease terms. It is stated that the asset residual value and life span must be revised to discover the efficacy of such PPE at the financial year-end. This depreciation is recognized as expenses and displayed on the debit side of the Profit and Loss account of the company. All companies, 
irrespective of their size, leverage this depreciation legally to circumvent the payment of tax to FIRS which is responsible for collecting taxes. Tax payable, according to Adegbite (2020) is a function depreciation value of PPE, which led to the following hypothesis.

\section{H2: Depreciation has an important effect on tax payable by Nigerian manufacturing companies}

\subsection{Long-term debt}

This is referred to as debt acquired outside the organization to complement the equity in order to finance it to achieve its predetermined and projected objectives. This is encapsulated in IAS39 which is a financial instrument. An organization recognized a financial asset and financial liability in the statement of financial position (previously the Balance Sheet) when the organization becomes a party to instrument contractual provisions. The interest and other costs expended in connection with financial asset and liabilities are deductible from Profit and Loss accounting, which invariably lessen taxation. If this debt is higher than the existing volume of equity, it is likely the organization has accrued higher profits aggressively. The interest paid at the end of the accounting period is recognized as expenses which ultimately downplay assessable profit, and thereby reduce tax payable to the government. Thus, taxation is a function of long-term debt. With this, the following hypothesis was generated:

\section{H3: Long-term debt plays a significant role on tax payable by Nigerian manufacturing companies}

\subsection{Noncurrent Asset}

According to IAS 16, this refers to assets which can be used for more than an accounting year of the organisation. This means that the economic benefits of such assets must flow into the organisation for longer than a period of an accounting year. The procurement of noncurrent assets for the repayment of inefficient assets attracts capital allowance through investment allowance, initial allowance and annual allowance, which are an allowable deduction in adjusted profit for tax purposes. The Annual Investment Allowance is a category of capital allowance which is the mechanism by which capital assets attract tax relief. For tax purposes, Annual Investment Allowance and other capital allowances are deducted from the accounting profit in order to arrive at taxable profits. This would usually qualify for the Annual Investment Allowance and as such the full cost would be allowable for tax purposes in the year of purchase. This perhaps reduces the tax payable to the government purse for the effective delivery of essential services for the population. Companies 
hide under this capital allowance to avoid payment of taxation to the government. Thus, the study hypothesized that:

\section{$\mathrm{H}_{4}$ : Noncurrent assets play a significant role in tax payable by Nigerian manufacturing companies}

\subsection{Profitability}

Taxation is a function of assessable profit meant to establish the corporate tax. It epitomises an organization's expenses which actually downplay expected profits. Management mostly feared the magnitude of inefficient market performance, which the leads to diminished investment because of low returns. However, this absolutely affects taxation, because the higher the assessable profit, the higher the taxation. Thus, the study hypothesized that:

$\mathrm{H}_{5}$ : Profitability has a negative impact on tax payable by Nigerian manufacturing companies

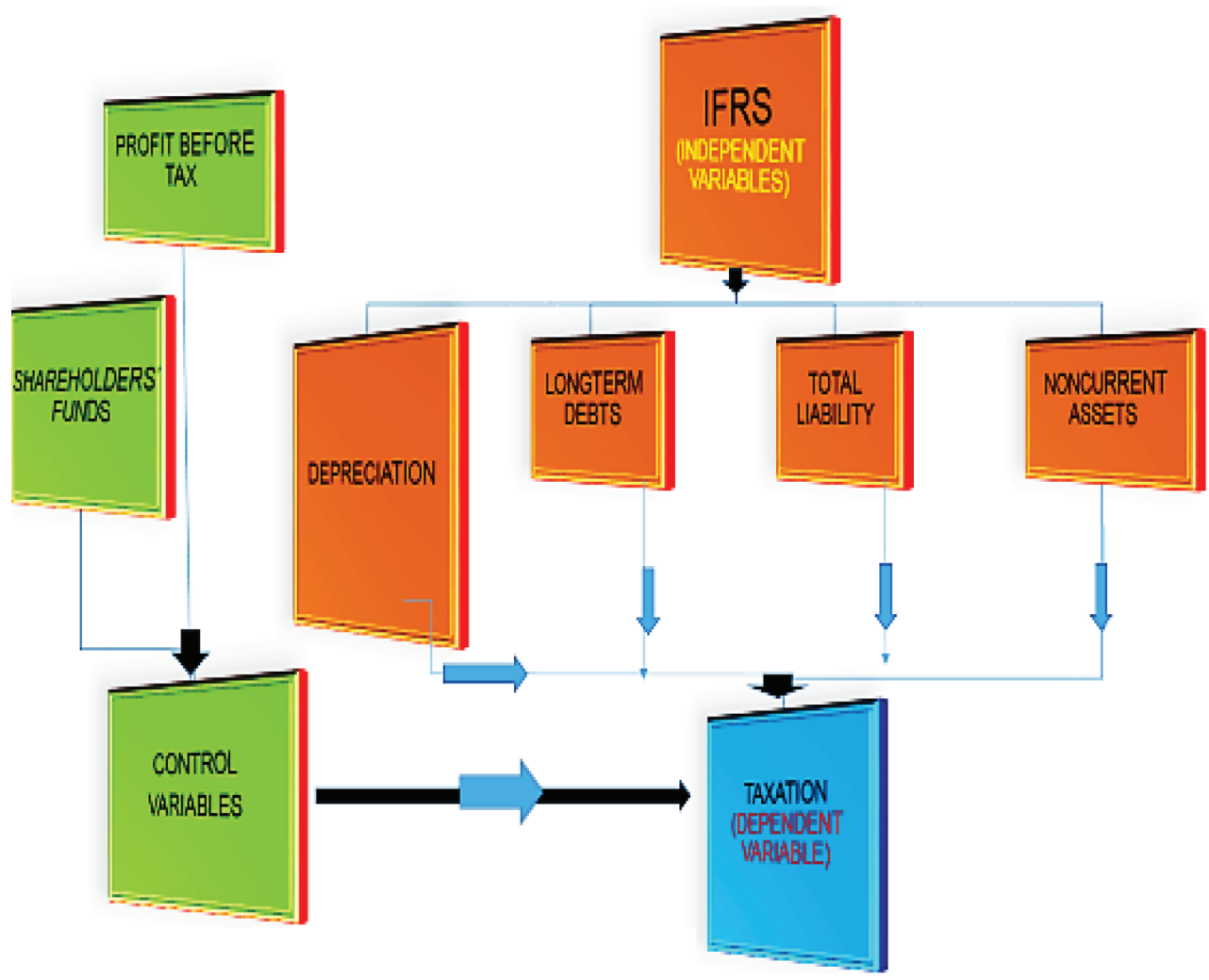

Fig. 1. Conceptual Framework. Authors' Design (2020)

Source: author's work. 


\subsection{Theoretical review}

\section{Constraints Theory (CT)}

The Constraints Theory (CT), according to Goldratt (1990), is an approach for recognising the most imperative limiting factor that stands as an obstacle in achieving a desire and goal, in order to circumspectly and absolutely circumvent such constraint, eradicate, or reduce to the barest level. CT is called a bottleneck in the manufacturing sector. This theory focuses on organisation enhancement via improved profitability and effective resources utilisation. Taxation has been regarded as an organisation bottleneck because of the profit motives and the maximization of shareholders' funds as a successful organisation's objectives. The objectives of every organisation are complemented with cost minimisation and profit maximization. To achieve these, management reduces taxation legally to siphon off the money or income that ought to have been remitted to the tax authority into the organisation's purse in terms of retained earnings or increased shareholders' wealth.

Implementing this theory, results in substantial organisation's improvement without reducing its resources, and the effective and efficient management of both human and material organisation resources. CT is applied to a restricted area and can only be executed with the minimal participation of the staff.

\section{Compliance Theory (COT)}

Compliance theory is a methodology to managerial structure that is key in several concepts from the participatory management and classical models. According to COT, organizations can be categorized by the variety of power engaged to manage; COT is a widespread approach which supports employees and their institutions in organizing activities and operations ethically based on acceptable norms, principle, standards; with the integrity of the highest order, and in compliance and alignment with acceptable legal and regulatory prerequisites. The theory advocated that the crucial determinants variables' compliance are the organization's and individual's personal levels of integrity, objectivity, morality, competency and moral development. IFRS is the accounting standard which has been mandated since 2011, the year of adoption for the uniformity and consistency in financial statement preparation. COT further advocated the absolute IFRS compliance which must be based on the integrity, competency, and objectivity of the manager who is given accounting and financial statement responsibilities.

Therefore, to achieve the study's objective and stated disposition, the author employed the Constraints Theory (CT) and Compliance Theory (COT). 


\subsection{Empirical review of the related studies}

Braga (2018) investigated the relationship between mandatory IFRS adoption and company tax avoidance. The data were gathered from 35 countries for publiclytrading companies in North America from 1999 to 2014. It was found that IFRS adoption has a meaningful association with corporate tax avoidance. The results showed that following the subsequent IFRS adoption, large firms with higher booktax conventionality environments were involved in tax avoidance more extensively than firms with lower book-tax conventionality environments. This outcome was based only on North America.

Nakao and Gray (2018) determined the IFRS benefits and impact on Brazilian organisations with particular reference to book-tax conformity and taxation regulation legacy. Their results predicted that limited stock market monitoring levels by companies demonstrated book-tax conformity with information quality enhancement. In the same vein, the results also showed that the companies' limited stock market monitoring levels are aligned with the expected quality information enhancement, connected with IFRS adoption in Brazil. However, this research outcome is confined to Brazil.

Abedana, Omane-Antwi and Owiredu (2016) investigated the variations of IFRS to deferred tax, corporate taxes, and net tax liabilities (assets) in the Ghana Stock Exchange from 2007 to 2008 which reflected the switch to IFRS from GNAS, with particular reference to IAS 12. The quantitative and cross-sectional approach was predominately adopted as the research model to achieve the study's objective. It was found that IFRS/IAS adoption led to relieving tax burden which invariably reduces tax payable by the listed companies. Nevertheless, the study was for Ghana not Nigeria, therefore its study's outcome cannot be applied to Nigeria.

David (2016) assessed the influence of IFRS adoption on Czech management accounting of unlisted companies. The results, with regard to the implemented questionnaire survey, showed that IFRS adopters progressively integrate IFRS ideologies into management accounting prediction, which invariably increased the Czech companies' performance. However, this study is based on IFRS within the scope of Czech unlisted companies, does not apply to Nigeria.

Yapa, Kraal \& Joshi (2015) inspected IFRS adoption and local standards' impact on socio-economic condition of the selected countries. Qualitative research was the adopted methodology embedded with the institutional and stakeholder theory in the study. Findings revealed that IFRS reduced the companies' tax payable which invariably displayed a negative effect on socio-economic condition of the selected countries, and not a single country, therefore the outcome generated is irrelevant to Nigeria.

Muller (2014) evaluated the impact of IFRS adoption on relative and absolute quality (proxied by value relevance) in European listed companies. The financial information was obtained through European stock markets. The results revealed that 
IFRS adoption increased the quality of the consolidated statements because of their transparency and disclosure. This study was limited to the relative and absolute quality (proxied by value relevance) in European listed companies in which taxation is totally not inclusive.

Fasina and Adegbite (2014) analysed empirically the effect of IFRS adoption on Nigerian accounting practices. The outcome of the questionnaire and personal interviews employed with Chi-square and ANOVA strongly indicated a positive relationship between IFRS adoption and organisations' financial performance. The study further advocated that the IFRS adoption effect improved the efficiency and productivity of organisations in terms of uniformity and quality of financial statements. However, its effect on Nigerian accounting practices was investigated but not on taxation, therefore the findings were confined to accounting practices and not to taxation policy.

The research gap was discovered due to the insufficient study which was also limited in scope (and not extended to 2018). The extant studies were initiated in Europe and in African countries such as Ghana but were limited to corporate tax. This study is unique because it highlights the effect on IFRS adoption on taxation (aggregation of VAT, education tax and corporate tax) which has had scant research in Nigeria.

\section{Methodology}

This study examined the IFRS adoption effect on companies' tax payable from 2012 to 2018. Data were gathered from yearly reports of selected 50 Nigerian listed companies, and scrutinised employing Pearson product moment correlation (PPMC) and panel data methodology to quantify the effect on tax payable. Depreciation, long-term debt, total liability and noncurrent assets are the independent variables, while taxation payable is the dependent variable and control variables are represented by shareholders' funds and profitability.

\subsection{Model specification}

Taxation which is the explained variable, is the aggregation of company income tax, education tax and VAT, while the explanatory variables are depreciation, long-term debt, total liability and noncurrent assets, and the control variables are represented by shareholders' funds and profitability.

$$
\begin{aligned}
\text { TAXATION }= & f(P B T, D E P R, S H D F U D, L G T D E B T, T O T L I A B, N O N C U R A S E T \mu),(1) \\
\sum_{i=1}^{n} \text { TAXATION }= & \alpha 0+\sum_{i=1}^{n} \alpha 1 P B T+\sum_{i=1}^{n} \alpha 2 D E P R+\sum_{i=1}^{n} \alpha 3 S H D F U D+\sum_{i=1}^{n} \alpha 4 L G T D E B T \\
& +\sum_{i=1}^{n} \alpha 5 T O T L I A B+\sum_{i=1}^{n} \alpha 6 N O N C U R A S E T+\mu 1,
\end{aligned}
$$


where: TAXATION - aggregation of VAT, education tax and corporate tax,

PBT - profit before tax,

DEPR - depreciation,

SHDFUD - shareholders' funds,

LGTDEBT - long term debt,

TOTLIAB - total liabilities,

NONCURASET- noncurrent assets.

\section{Results and discussion}

This section presents the results obtained from the analysis of data collected from annual reports of fifty selected Nigeria listed companies. These data were scrutinised by employing PPMC and panel data methodology to quantify the IFRS adoption effect on tax payable.

Table 1 showed that a unit increase in PBT raised taxation by $0.23 \%$, revealing that PBT generated a positive effect on taxation $(\beta=.2343325, t=0.000<0.05)$. A one unit increase in depreciation led to a decrease in taxation by $0.024 \%$, indicating that there is a positive effect of DEPR on taxation $(\beta=-.0240423, t=0000<0.05)$. However, a unit increase in SHDFUD led to a decrease in taxation by $0.11 \%$, which further indicates that there was a negative effect of SHDFUD on taxation $(\beta=-.0112534$, $t=0000>0.05)$. The result also shows that a unit increase in LGTDEBT decreased taxation by $0.032 \%$, indicating that there is a negative effect of LGTDEBT on Taxation $(\beta=-.0321145, \mathrm{t}=0.003<0.05)$. Moreover, a one unit increased in TOTLIAB decreased Taxation by $0.041 \%$ which indicates that there was a negative effect of TOTLIAB on taxation $(\beta=-.0412378, t=0.002<0.05)$. It was also found that a unit increase in NONCURASET decreased taxation by $5.67 \%$, which reveals a negative effect occurring between NONCURASET and taxation $(\beta-5.67345, t=0.000>0.05)$.

Table 1. Pooled model on the IFRS adoption effect on taxation in Nigerian manufacturing companies

\begin{tabular}{|c|c|c|c|c|c|c|}
\hline $\begin{array}{l}\text { Dependent } \\
\text { variable }\end{array}$ & $\begin{array}{l}\text { Independent } \\
\text { variables }\end{array}$ & Coefficient & Standard & $\mathrm{T}$ & $\mathrm{P}>/ \mathrm{T} /$ & (95\% conf. Interval) \\
\hline \multirow[t]{7}{*}{ TAXATION } & PBT & .2343325 & 0.030237 & 7.75 & 0.000 & $\begin{array}{ll}2994952 & .3003698 \\
\end{array}$ \\
\hline & DEPR & -.0240423 & 0.004857 & -4.95 & 0.001 & $\begin{array}{ll}-.0007791 & .0006924 \\
\end{array}$ \\
\hline & \begin{tabular}{|l|} 
SHDFUD \\
\end{tabular} & -.0112534 & 0.001931 & -5.83 & 0.000 & $\begin{array}{|ll|}-.0003215 & .0000536 \\
\end{array}$ \\
\hline & LGTDEBT & -.0321145 & 0.009336 & -3.44 & 0.003 & $\begin{array}{|ll|}-.0060524 & .0012578 \\
\end{array}$ \\
\hline & TOTLIAB & -.0412378 & 0.009889 & -4.17 & 0.002 & $\begin{array}{ll}.0000644 & .0004927 \\
\end{array}$ \\
\hline & NONCURASET & -5.67345 & 0.811653 & -6.99 & 0.000 & $\begin{array}{|ll|}-.0000429 & .0000298 \\
\end{array}$ \\
\hline & CONSTANT & 5.893458 & 0.406726 & 14.49 & 0.000 & $\begin{array}{|ll|}-7400.187 & 122531.8 \\
\end{array}$ \\
\hline $\begin{array}{c}\text { R squared }= \\
0.6734\end{array}$ & $\begin{array}{c}\text { Adj } \\
\text { R squared }=0.5892\end{array}$ & $\begin{array}{c}\text { Prob }> \\
F=0.0000\end{array}$ & \multicolumn{3}{|c|}{ Root $\mathrm{MSE}=2.5 \mathrm{e}+05$} & $F(6,62)=789.21$ \\
\hline
\end{tabular}

Source: researcher's computation. 
$\mathrm{R}^{2}$ and adjusted $\mathrm{R}^{2}(0.6734$ and 0.5892 respectively) proved that the incorporated variables were sufficient and fitted to pronounce the IFRS adoption effects on manufacturing companies' tax payable. This was also confirmed by $F$ Probability 0.000 which is the benchmark for the significance of the model.

Table 2 shows that a unit increase in profit before tax increased taxation by $0.29 \%$, and revealed that PBT generated a positive effect on taxation $(\beta=.2999325$, $t=0.000<0.05$ ). A one unit increase in depreciation led to a decrease in taxation by $0.010 \%$, indicating that there was a negative effect of DEPR on taxation $(\beta=-.0100434, t=0000<0.05)$. However, a unit increase in SHDFUD led to a decrease in taxation by $0.131 \%$, which further indicates that there was a negative effect of SHDFUD on taxation $(\beta=-.0131339 \mathrm{t}=0000>0.05)$. The result also shows that a unit increase in LGTDEBT decreased taxation by $0.023 \%$, indicating that there was a negative effect of LGTDEBT on Taxation $(\beta=-.0236551, t=0.000<0.05)$. Additionally, a one unit increase in TOTLIAB decreased Taxation by $0.302 \%$, proving that there was a negative effect of TOTLIAB on Taxation $(\beta=-.0302141$, $t=0.002<0.05)$. It was also found that a unit increase in NONCURASET decreased taxation by $6.52 \%$, which reveals a negative effect of NONCURASET on taxation $(\beta=-6.524324, t=0.000>0.05)$.

Table 2. Random model on the IFRS adoption effect on taxation in Nigerian manufacturing companies

\begin{tabular}{|c|c|c|c|c|c|c|}
\hline $\begin{array}{l}\text { Dependent } \\
\text { variable }\end{array}$ & $\begin{array}{l}\text { Independent } \\
\text { variables }\end{array}$ & Coefficient & $\begin{array}{l}\text { Standard } \\
\text { error }\end{array}$ & $\mathrm{T}$ & $\mathrm{P}>/ \mathrm{T} /$ & ( $95 \%$ conf. Interval) \\
\hline \multirow[t]{7}{*}{ Taxation } & PBT & .2999325 & 0.042185 & 7.11 & 0.000 & $\begin{array}{|ll|}.2995037 & .3003612 \\
\end{array}$ \\
\hline & DEPR & -.0100434 & 0.002438 & -4.12 & 0.000 & $\begin{array}{|ll|}-.0007647 & .000678 \\
\end{array}$ \\
\hline & SHDFUD & -.0131339 & 0.002419 & -5.43 & 0.000 & $-.0003178 \quad .000050$ \\
\hline & LGTDEBT & -.0236551 & 0.007756 & -3.05 & 0.006 & $\begin{array}{lll}.0060056 & -.0013046\end{array}$ \\
\hline & TOTLIAB & -.0302141 & 0.008535 & -3.54 & 0.002 & $\begin{array}{ll}-.000059 & .0004872\end{array}$ \\
\hline & NONCURASET & -6.524324 & -1.025837 & -6.36 & 0.000 & $\begin{array}{|ll|}.0000422 & .0000291 \\
\end{array}$ \\
\hline & CONSTANT & 57565.8 & 5345.014 & 10.77 & 0.000 & $-6132.454 \quad 121264$ \\
\hline \multicolumn{2}{|c|}{$\begin{array}{c}\text { R-squared within }=0.6734 \\
\text { between }=0.5563 \\
\text { overall }=0.7532\end{array}$} & \multicolumn{2}{|c|}{ Prob $>$ chi $^{2}=0.000$} & \multicolumn{3}{|c|}{ Wald chi2 $(6)=2.58 \mathrm{e}+07$} \\
\hline
\end{tabular}

Source: researcher's computation.

Table 3 shows that a unit increase in Profit Before Tax increased taxation by $0.30 \%$, and reveals that PBT generated a positive effect on taxation $(\beta=.3000541$, $t=0.000<0.05$ ). A one unit increase in depreciation led to a decrease in taxation by $0.015 \%$, indicating that there was a negative effect of DEPR on taxation $(\beta=-.01500909, t=0.004>0.05)$. However, a unit increase in SHDFUD led to a decrease in taxation by $0.121 \%$, and it further indicates that there was a negative effect of SHDFUD on taxation $(\beta=-.0120656, t=0.010>0.05)$. The result also 
Table 3. Fixed model on the IFRS adoption effect on taxation in Nigerian manufacturing companies

\begin{tabular}{|c|c|c|c|c|c|c|}
\hline $\begin{array}{l}\text { Dependent } \\
\text { variable }\end{array}$ & $\begin{array}{l}\text { Independent } \\
\text { variables }\end{array}$ & Coefficient & $\begin{array}{c}\text { Standard } \\
\text { error }\end{array}$ & $\mathrm{T}$ & $\mathrm{P}>/ \mathrm{T} /$ & ( $95 \%$ conf. Interval) \\
\hline \multirow[t]{7}{*}{ TAXATION } & PBT & .3000541 & 0.038078 & 7.88 & 0.000 & $\begin{array}{|ll|}.2997198 & .3003885 \\
\end{array}$ \\
\hline & DEPR & -.0150909 & 0.00238 & -4.24 & 0.004 & $\begin{array}{|ll|}-.0006843 & .0008661 \\
\end{array}$ \\
\hline & SHDFUD & -.0120656 & $1.67 \mathrm{E}-05$ & -3.92 & 0.010 & $\begin{array}{|ll|}.0002084 & .0000772 \\
\end{array}$ \\
\hline & LGTDEBT & -.0086099 & 0.001117 & -7.71 & 0.000 & $\begin{array}{|ll|}.0108483 & -.0063714 \\
\end{array}$ \\
\hline & TOTLIAB & -.022094 & $1.93 \mathrm{E}-05$ & -4.86 & 0.001 & $\begin{array}{|ll|}.0001252 & .0003132\end{array}$ \\
\hline & NONCURASET & -2.326756 & 0.450049 & -5.17 & 0.000 & $\begin{array}{|ll|}.0000252 & .0000298 \\
\end{array}$ \\
\hline & CONSTANT & 78185.42 & 6200.271 & 12.61 & 0.000 & \begin{tabular}{|ll}
18182.5 & 138188.3 \\
\end{tabular} \\
\hline \multicolumn{2}{|c|}{$\begin{array}{c}\text { R-squared within }=0.0654 \\
\text { between }=0.4325 \\
\text { overall }=0.7865\end{array}$} & \multicolumn{2}{|c|}{ Prob $>$ chi $^{2}=0.000$} & \multicolumn{3}{|c|}{$F(6,53)=2.74 \mathrm{e}+06$} \\
\hline
\end{tabular}

Source: researcher's computation.

shows that a unit increase in LGTDEBT decreased Taxation by $0.0080 \%$, indicating that there was a negative effect of LGTDEBT on taxation $(\beta=-.0086099, t=0.000$ $<0.05)$. Furthermore, a one unit increase in TOTLIAB reduced taxation by $0.022 \%$, proving that there was a negative effect of TOTLIAB on taxation $(\beta=.022094$, $t=0.001<0.05)$. It was also found that a unit increase in NONCURASET decreased taxation by 2.32 which shows a negative effect of NONCURASET on Taxation $(\beta=-2.326756, t=0.000>0.05)$.

Table 4 shows the Hausman test decision for fixed and random effects. The Hausman test advocated the consideration of the random effect model as the appropriate model for the analysis and interpretation. Therefore, the fixed effect was rejected because $\mathrm{chi}^{2}<0$ is 203.46, which is higher than 0.05 .

Table 4. The Hausman test

\begin{tabular}{|c|c|c|c|c|c|}
\hline $\begin{array}{l}\text { Dependent } \\
\text { variable }\end{array}$ & $\begin{array}{l}\text { Independent } \\
\text { variables }\end{array}$ & $\begin{array}{l}\text { Coefficient } \\
\text { (b) }\end{array}$ & $\begin{array}{l}\text { Coefficient } \\
\text { (B) }\end{array}$ & $\begin{array}{c}(\mathrm{b}-\mathrm{B}) \\
\text { Difference }\end{array}$ & $\begin{array}{c}\text { Sqrt } \\
(\operatorname{diag}(v-b-v-B)) \text { S.E }\end{array}$ \\
\hline \multirow[t]{6}{*}{ TAXATION } & PBT & .2999325 & .3000541 & -0.00012 & .0001416 \\
\hline & DEPR & -.0100434 & -.0150909 & -0.01013 & \\
\hline & SHDFUD & -.0131339 & -.0120656 & -0.00107 & .0000611 \\
\hline & LGTDEBT & -.0236551 & -.0086099 & -0.01505 & .000439 \\
\hline & TOTLIAB & -.0302141 & -.022094 & 0.00812 & .0000864 \\
\hline & NONCURASET & -6.524324 & -2.326756 & -4.19757 & .0000119 \\
\hline \multicolumn{2}{|c|}{$\begin{array}{c}\mathrm{b}=\text { consistent under Ho } \\
\text { and } \mathrm{Ha}\end{array}$} & \multicolumn{2}{|c|}{$\begin{array}{c}\mathrm{B}=\text { inconsistent under Ha, } \\
\text { efficient under } \\
\text { Ho }\end{array}$} & \multicolumn{2}{|c|}{$\begin{array}{l}\text { Test: Ho: difference in coefficients } \\
\text { not systematic } \\
\begin{array}{c}\text { Chi2 (6) }=(b-B){ }^{\prime}\left[(\mathrm{v}-\mathrm{b}-\mathrm{v}-\mathrm{B})^{\wedge}(-1)\right] \\
(\mathrm{b}-\mathrm{B})=203.46 \\
\mathrm{Chi}^{2}<0.0000\end{array}\end{array}$} \\
\hline
\end{tabular}

Source: researcher's computation. 
Table 5. Correlation matrix - the IFRS adoption effects on taxation in Nigerian manufacturing company

\begin{tabular}{|l|c|c|c|c|c|c|c|}
\hline & Taxation & PBT & DEPR & SHDFUD & LGTDEBT & TOTLIAB & NONCURASET \\
\hline Taxation & $\mathbf{1 . 0 0 0 0}$ & & & & & & \\
\hline PBT & $\mathbf{0 . 3 6 0 0 *}$ & $\mathbf{1 . 0 0 0 0}$ & & & & & \\
\hline DEPR & $\mathbf{- 0 . 0 3 1 0}$ & $\mathbf{- 0 . 0 3 1 0}$ & $\mathbf{1 . 0 0 0 0}$ & & & & \\
\hline SHDFUD & $\mathbf{0 . 3 4 9 6 *}^{*}$ & $\mathbf{0 . 0 4 9 6 *}$ & $\mathbf{- 0 . 0 3 2 6}$ & $\mathbf{1 . 0 0 0 0}$ & & & \\
\hline LGTDEBT & -0.0482 & $\mathbf{- 0 . 0 4 7 6}$ & $\mathbf{0 . 0 6 0 0}$ & $\mathbf{- 0 . 0 3 3 4}$ & $\mathbf{1 . 0 0 0 0}$ & & \\
\hline TOTLIAB & $-0.4477^{*}$ & $\mathbf{0 . 5 4 7 6 *}$ & $\mathbf{0 . 0 3 4 4}$ & $\mathbf{0 . 6 8 7 1} *$ & $\mathbf{0 . 0 2 1 9}$ & $\mathbf{1 . 0 0 0 0}$ & \\
\hline NONCURASET & $-\mathbf{0 . 6 0 7 2}^{*}$ & $\mathbf{0 . 6 0 7 1 *}$ & $\mathbf{- 0 . 0 2 4 7}$ & $\mathbf{0 . 7 1 2 6 *}$ & $\mathbf{0 . 0 2 3 9}$ & $\mathbf{0 . 7 5 4 0 *}$ & $\mathbf{1 . 0 0 0 0}$ \\
\hline
\end{tabular}

Source: researcher's computation.

Table 5 shows the correlation between taxation payable and IFRS adoption. It was found that PBT has a positive stimulus on taxation payable (0.3600). DEPR declared a negative insignificant nexus on tax payable (-0.0310). This demonstrated that the greater the impairment of assets through depreciation, the lesser the tax payable to the government. SHDFUD has a positive significant nexus with taxation, since when shareholders' funds increase, profitability will rise which in turn will increase assessable profit, thereby incrementing tax payable. LGTDEBT also reduces tax payable as shown in Table $5(-0.0482)$. This clearly showed that company aggressiveness on financing reduces taxation when debt is greater than equity. TOTLIAB also displayed a negative significant nexus with tax payable $\left(-0.4477^{*}\right)$. NONCURASET in the same vein displayed a negative significant nexus with tax payable, and this revealed that investment in NONCURASET reduces tax payable through capital allowance, by which companies circumspectly and legally circumvent tax payment. No multicollinearity existed among the variables because their correlation values are less than 0.8 where multicollinearity exists.

\subsection{Discussion of findings}

The results obtained from the analysis proved that there is a positive effect of PBT on taxation, as suggested by Haverals (2007). This demonstrated that the higher the PBT declared by the organisation, the higher the tax payable to the government. Depreciation, as was revealed, reduces taxation because the wear and tear of assets led to the inefficiency of the operation in an organisation which in the long run deters increased profitability which is the prerequisite determinacy of tax payable. Additionally, an increase in SHDFUD reduced taxation which is tantamount to the negative effect of SHDFUD on taxation. The maximization of shareholders' wealth objective of the organisation circumspectly paved the way for the legality of tax avoidance because additional shareholders' funds caused lower profits as supported by Abedana et al. (2016). LGTDEBT negatively affects Taxation, as any company that is aggressively financed experiences a reduction in assessable profits because the income realised as a profit is spent on loan repayments and interest which are 
deductible from assessable profit. Moreover, a unit rise in TOTLIAB reduces TAXATION as stated by Yapa et al. (2015), who predicted a negative effect on TAXATION. NONCURASET reduces taxation because the procurement of new assets attracts capital allowance such as initial, investment and annual allowance which are deductible from the assessable profit of the organisation. The higher the procurement of NONCURASET, the lesser the assessable profit which is in line with tax payable reduction.

\section{Conclusion and recommendations}

This study examined the IFRS adoption effect on the companies' tax payable from 2012 to 2018. The data gathered from annual reports of fifty selected Nigerian listed companies were scrutinised employing PPMC and panel data methodology to quantify the IFRS adoption effect on tax payable. This revealed that PBT caused a significant positive effect on TAXATION, whilst DEPR, TOTLIAB, SHDFUD, LGTDEBT and NONCURASET impacted on TAXATION negatively. This showed that an increase in DEPR, TOTLIAB, SHDFUD, LGTDEBT and NONCURASET decreased taxation in an entity. Conclusively, IFRS adoption significantly reduced organisation tax payable because organisations circumspectly and lawfully circumvent or reduce the tax payable through depreciation claimed on existing assets, procurement of new noncurrent assets, and long-term debt (leverage) as shown by Yapa, et al. (2015). It is advocated that there should be monitoring mechanisms or devices put into motion by the government to monitor organisations' procurement, impairment of assets and debts acquired transparently, in order to deter unnecessary and artificial reductions in tax payable.

The results are supportive for countries that have adopted IFRS and are also reliant on exports, oil extraction and industry in understanding the dynamic IFRS adoption effect on taxation income. However, the pertinent contributions of study are that it employed Panel models through Fixed, Random, and pooled methods to display the IFRS adoption effect on taxation. This study is relevant to government officials responsible for tax collection, and for taxation policymakers in order to comprehend the bottlenecks caused by the IFRS adoption on loopholes for legal and lawful tax avoidance by the manufacturing sector. This paper has some limitation, first and foremost, the sample data obtained from annual published reports were scant. Secondly, the data custodians' attitude toward releasing the crucially needed data constricted and elongated the duration of this research.

The findings were established based on scientific literature and the selected manufacturing companies examined, therefore it is recommended that subsequent research expands the knowledge on this aspect of the study. The subsequent study can be extended to banks, education, the mining industry and agricultural sectors in Nigeria to gauge the effect of IFRS adoption effect on tax payable. Additionally, the IFRS adoption effect on bank performance can also be investigated because it is pertinent. 


\section{References}

Abedana, V. N., Omane-Antwi, K. B., \& Owiredu, A. (2016). The impact of IFRS/IAS adoption on corporate income taxation in Ghana. International Journal of Accounting and Financial Reporting, 6(1), 72-98.

Albu, N., \& Albu, C. N. (2012), International financial reporting standards in an emerging economy: Lessons from Romania. Australian Accounting Review, 22(4), 341-52.

Adegbite T. A. (2020). An investigation on the influence of taxation on economic growth in Nigeria. Academic Journal of Economic Studies, 6(2), 12-20.

Al-Htaybat, K. (2017), IFRS adoption in emerging markets: The case of Jordan. Australian Accounting Review, 22 (4), 1-20.

David, P. (2016). Specifics of IFRS adoption by Czech private companies (19th International Conference Enterprise and Competitive Environment, ECE. Procedia Social and Behavioral Sciences, 220, pp. 363-372).

Eberhartinger, E., \& Klostermann, M. (2007). What if IFRS were a tax base? New empirical evidence from an Austrian perspective. Accounting in Europe, 4(2), 141-168.

Ezejiofor, R. A. (2018). Effect of IFRS on value relevance of accounting information: Evidence from quoted manufacturing firms in Nigeria. International Journal of Trend in Scientific Research and Development (IJTSRD), 2(5), 2255-2291.

Fasina, H. T., \& Adegbite, T. A. (2014). Empirical analysis of the effect of international financial reporting standard (IFRS). Adoption on accounting practices in Nigeria. Archives of Business Research, 2(2), 1-14.

Goldratt, Eliyahu, M. (1990). What is this thing called theory of constraints and how should it be implemented? Great Barrington, Mass.: The North River Press.

Goodwin, J., \& Ahmed, K. (2006). The impact of international financial reporting standards: Does size matter? Managerial Auditing Journal, 21(5), 460-475.

Goodwin, J., Ahmed, K., \& Heaney, R. (2007). The effects of international financial reporting standards on the accounts and accounting quality of Australian firms: A retrospective study., Journal of Contemporary Accounting and Economics, 4(2), 89-119.

Hanlon, M., Laplante, S. K., \& Shevlin, T. (2005). Evidence for the possible information loss of conforming book income and taxable income. The Journal of Law and Economics, 4(8), 407-420.

Haverals, J. (2007). IAS/IFRS in Belgium: Quantitative analysis on the impact on the tax burden of companies. Journal of International Accounting, Auditing and Taxation, 16(1), 69-89.

Josiah, M., Okoye, A. E., \& Adediran, O. S. (2013). Accounting standards in Nigeria, the journey so far. Research Journal of Business Management and Accounting, 2(1), 1-10.

Larson, R. K., \& Street, D. L. (2004). Convergence with IFRS in an expanding Europe: Progress and obstacles identified by large accounting firms' survey. Journal of International Accounting, Auditing and Taxation, 1(3), 89-119.

Muller, V. O. (2014). The impact of IFRS adoption on the quality of consolidated financial reporting. (2nd World Conference on Business, Economics and Management. WCBEM. Procedia - Social and Behavioral Sciences, pp. 976-982).

Mulyadi, M. S., Soepriyato, G., \& Anwar, Y. (2012). IFRS adoption and taxation issue. International Journal of Arts and Commerce, 1(7), 159-165.

Nakao, S. H., \& Gray, S. J. (2018). The impact of IFRS in Brazil: The legacy of mandatory book-tax conformity. Australian Accounting Review, 22(4), 1-14

Nevius, A. (2008). How will IFRS affect tax practitioners? Journal of Accountancy, 20(6), 100-120.

Nobes, C. (1994). A study of the International Accounting Standards Committee. Albert Robins and Co Ltd.

Ramona, N. (2014). The effects of IFRS on net income and equity: Evidence from Romanian listed companies. Emerging markets queries in finance and business (Procedia - Economics and Finance, pp. 1787-1790). 
Upton, W. (2010, April 16). Adopt, adapt, converge? Retrieved from http://www.ifrs.org/News/Features/Adopt+adapt+converge.htm

Yapa, P. W. S., Kraal, D., \& Joshi, M. (2015). The adoption of 'International Accounting Standard (IAS) 12 Income Taxes': Convergence or divergence with local accounting standards in selected ASEAN countries? Australasian Accounting, Business and Finance Journal, 9(1), 3-24.

\section{WPLYW IMPLEMENTACJI MIĘDZYNARODOWYCH STANDARDÓW SPRAWOZDAWCZOŚCI FINANSOWEJ NA WYSOKOŚĆ OPODATKOWANIA NIGERYJSKICH PRZEDSIĘBIORSTW PRODUKCYJNYCH}

Streszczenie: W artykule przedstawiono wyniki badań nad wpływem zastosowania przez nigeryjskie przedsiębiorstwa produkcyjne MSSF na ich wysokość opodatkowania w latach 2012-2018. Podstawą analizy były dane z raportów rocznych 50 wybranych nigeryjskich spółek giełdowych. Dane przeanalizowano z zastosowaniem metodologii PPMC i analizy danych panelowych. Badania pokazały, że zysk przed opodatkowaniem miał pozytywny i znaczny wpływ na wysokość zobowiązania podatkowego, a amortyzacja, kapitał własny, zobowiązania długoterminowe i aktywa trwałe - negatywny. Zatem wzrost amortyzacji, kapitałów własnych, zobowiązań długoterminowych i aktywów trwałych zmniejszył wysokość podatku w analizowanych firmach produkcyjnych. Przyjęcie MSSF znacznie obniżyło zobowiązania podatkowe przedsiębiorstw produkcyjnych, gdyż podmioty te ostrożnie i zgodnie z prawem obchodziły lub zmniejszały podatek, wykorzystując odpisy amortyzacyjne oraz zobowiązania długoterminowe (stosując dźwignię finansową). Autorzy zalecają wprowadzenie przez rząd mechanizmów monitorujących, aby kontrolować zamówienia firm, utratę wartości aktywów i nabytych długów w sposób przejrzysty w celu powstrzymania sztucznego obniżania zobowiązań podatkowych.

Słowa kluczowe: amortyzacja, opodatkowanie, kapitał własny, zobowiązania długoterminowe, aktywa trwałe, MSSF (IFRS). 